UDC: 81'243(497.11); 371.3::811(497.11)

\title{
SETTING COMMON STANDARDS IN FOREIGN LANGUAGE TESTING - ALIGNING SERBIA WITH THE REST OF THE WORLD
}

\author{
RADMILA BODRIČ 1 \\ University of Novi Sad, Faculty of Philosophy, \\ Department of English Language and Literature, \\ Novi Sad, Serbia \\ KRIŠTOF-KAROLJ BODRIČ \\ Foreign Language Centre Lingua \\ Novi Sad, Serbia
}

Cilj ovog rada je da pruži pregled testiranja stranih jezika u Srbiji, trenutno stanje i moguće korake ka uvođenju jedinstvenog standarda koji bi unapredio kvalitet testiranja stranih jezika i nastavu stranih jezika. Pored toga, takav standard bi omogućio da se izbegnu nepotrebna testiranja kao i nepotreban dodatni rad kako nastavnika, tako i učenika. Iz svega ovog se, dakle, može izvesti zaključak da je uvođenje standarda imperativ.

Ključne reči: testiranje stranih jezika, Srbija, jedinstveni standard, nastavnici, učenici.

\section{INTRODUCTION}

Standardised language tests provide a universal and non-biased assessment of all students taking them. Despite many assaults on standardised tests as they exist today, one cannot deny the fact that admission and placement decisions are best addressed by a norm-referenced or standardised test. If an institution is to make informed entrance decisions on students' proficiency, being fair and accountable for its admission decisions, then a standardised test is essential. When it comes to the Serbian educational context though, the current situation in standardised foreign language testing is far from satisfactory. With no officially accredited assessment and testing body which would be responsible for aligning the national foreign language curriculum

1 Kontakt podaci (Email): radmila.bodric@gmail.com 
and examinations with the Common European Framework of Reference for Languages (CEFR), with teachers using different testing practices largely based on their personal preference and understanding of what language learning is or should be, and with the number of pupils ranging from 30 to 40 per class, the need for standardised testing is more urgent than ever.

\section{FOREIGN LANGUAGE EDUCATION IN SERBIA AND THE IMPORTANCE OF CHANGE}

Since the very start of the Education Reform process in 2001 the Serbian Ministry of Education has recommended the use of foreign language textbooks published by Cambridge University Press, 0xford University Press and other foreign publishers in primary and general secondary education. A survey carried out in 2004/2005 showed that these new textbooks were only partially introduced, so that it was often the case that both 'old' and 'new' textbooks were used within the same state school, whereas at present new textbooks are being used exclusively (Vlaisavljević 2005: 238).

This clearly shows that state schools, like all public organisations, are rather slow to accept change, even if they are aware that change necessarily brings room for improvement of the current state of affairs. Teachers who are, by definition, the driving force of all change or innovation are, in our period of transition, lethargic, and satisfied with the status quo. Numerous and diverse formal and informal, institutional and individual activities or measures which should be employed to implement standardisation are likely to encounter resistance due to this inertia. Standardisation will certainly happen, as long as all interested parties are aware of its importance but, much to the regret of progressive institutions, this will happen rather gradually.

Now, the question arises as to why change is needed. In the first place, standardisation/change is indispensable so foreign language courses would truly correspond to (EFR Levels (Bodrič 2007, 2008). Only in that way would the transition to further levels at higher instances of education be facilitated. By providing clear and smooth progression we could actually provide appropriate and accurate streaming according to language proficiency within existing groups of learners with a minimum of effort, and eliminate redundant testing and unnecessary courses.

Alarge number of Serbian citizens possess a range of foreign language qualifications acquired from a variety of sources such as international language certificates (Cambridge ESOL (English for Speakers of Other Languages), IELTS (International English Language Testing System), TOEFL (Test of English as a Foreign Language), DELF (Diplôme d'études en langue française), DALF (Diplôme approfondi de langue française), etc.), certificates from foreign language schools, successfully completed courses as part of their school curricula, etc. Sadly, these qualifications are more often than not little more than decorations which they can frame and give them pride of place above the mantelpiece since, due to the lack of standardisation, they will seldom be recognised by bodies other than the issuing ones. Stories abound of students in possession of A-grade pass certificates in CAE (Cambridge Certificate in Advanced English) (Level (1) being made 
to take a B1 or even $\mathrm{A} 2$ level course at university simply because there is no regulatory mechanism in place for the recognition of such qualifications. The essential point is: Why would a learner take a course or level $s /$ he has already mastered, provided there is no higher level than the ones offered? Standardisation and accreditation could by all means eliminate this problem as well as the sheer waste of time, labour and money associated with it.

Many universities and other educational institutions worldwide recognise CAE (in some cases even FCE (First Certificate in English) (Level B2), IELTS or TOEFL for English language entrance requirements. Although the Serbian Ministry of Education officially recognised Cambridge ESOL examinations almost five years ago, this decision is only sporadically implemented, especially when it comes to university education. This is regrettable because these are the very institutions that would benefit most from their official recognition. Companies, on the other hand, have long recognised international exams for the purpose of employment and promotion (Graddol 2006).

Although it is not appropriate to make value judgements, one cannot but notice that what seems to be at issue here is not the Serbian national language education policy or curriculum as such but the implementation and monitoring of the standards defined. In order to contribute more fully to the development of quality language education, standardised language proficiency testing, as mentioned earlier, should become an important part of the Serbian education system for it would undoubtedly raise the standards of foreign language (L2) learning, teaching and assessment and facilitate the recognition of language qualifications from a wide range of sources. In order for this to happen, additional training and seminars should be organised for teachers by language testing experts who would impart to them knowledge, experience and support. To say, however, that language testing experts in our country are few and far between would be an understatement. This alone is likely to thwart any serious attempt at introducing any far-reaching reforms. This could be addressed in two ways: either by inviting a group of renowned experts from abroad or better still by training local methodologists and language testers in the field of testing, thus enabling them to carry out the work themselves as well as to transfer their knowledge to others.

When it comes to university education, we must point out that foreign language teachers often have almost unlimited discretionary rights in choosing course books as well as constructing and administering tests with little or no external validation at all. The only exception to the rule, though only partially, would be entrance examinations at particular universities.

For instance, the new Curriculum and Syllabus at the English Department of the Faculty of Philosophy in Novi Sad aims to bring all students of English as a foreign language to the Council of Europe C2 Level (ALTE (The Association of Language Testers in Europe) Level 5 - 'Mastery'). 


\begin{tabular}{|c|c|c|}
\hline $\begin{array}{c}\text { The ALTE Framework } \\
\text { Levels of Language } \\
\text { Competence }\end{array}$ & $\begin{array}{c}\text { The CEFR Levels of } \\
\text { Language Competence }\end{array}$ & $\begin{array}{c}\text { Cambridge ESOL } \\
\text { Examinations }\end{array}$ \\
\hline ALTE Breakthrough & A1 & KET (Key English Test) \\
\hline ALTE Level 1 & A2 & $\begin{array}{c}\text { PET (Preliminary English } \\
\text { Test) }\end{array}$ \\
\hline ALTE Level 2 & B1 & $\begin{array}{c}\text { FCE (First Certificate in } \\
\text { English) }\end{array}$ \\
\hline ALTE Level 3 & B2 & $\begin{array}{c}\text { CAE (Certificate in Advanced } \\
\text { English) }\end{array}$ \\
\hline ALTE Level 4 & C1 & $\begin{array}{c}\text { CPE (Certificate of } \\
\text { Proficiency in English) }\end{array}$ \\
\hline ALTE Level 5 & C2 \\
\hline
\end{tabular}

Table 1: Equivalent levels of language competence and Cambridge ESOL examinations according to the ALTE Framework and CEFR (www.alte.org)

Therefore, in order to make the studies more efficient, the proposal has been made that students enrolling in the programme should already be excellent at B1 Level (ALTE Level 2) or at least average at B2 level (ALTE Level 3). The entrance exam speaking test materials are designed accordingly, to test the limits of the candidate's ability through a series of speaking tasks of increasing difficulty up to the threshold of Level C1 (i.e. to the upper band of Level B2). Experience indicates that some candidates at the Entrance Examination are already able to achieve, and in some cases exceed this level of communication. This is an attempt, albeit isolated, at $L 2$ testing standardisation practice, although it lacks uniformity on the national level since no attempt has been made to co-ordinate the entrance examinations at different Serbian universities. In the same vein, there is no regulatory mechanism in place to recognise high-quality international foreign language certificates, which, as has been previously mentioned, inevitably leads to redundant courses and waste of time and labour. Therefore, regulations should be passed so as to include a number of high-quality international examinations and other high-quality certificates which would enable streaming and automatic awarding of grades in equivalent courses to foreign language students, based on the certificates they already possess. Apart from regulations, close cooperation must be established between educational institutions and certificate issuing bodies in Serbia. Setting up a viable accreditation programme would ensure meaningful accreditation to more forward-looking schools and universities, and validation of their certificates. 


\section{PRIVATE LANGUAGE SCHOOLS: PROS \& CONS}

It is not without pride that we are able to say that private foreign language schools in Serbia are at the forefront of foreign language teaching, learning and assessment. By organising tuition in small groups of five to ten learners, by being flexible and progressive, they are the first to adopt the latest developments in foreign language teaching. By far the greatest penetration of international examinations into the Serbian market has been through private language schools. Awareness is raised in teaching and management staff of the importance of international standardised examinations and of the benefits that schools obtain from promoting and incorporating them. Therefore, it is to these schools that we mostly owe the current level of standardisation and the good pass rates in examinations. A number of them have fully integrated and promoted European quality standards for language teaching and testing provision. As with staterun schools, there is a substantial fluctuation in the quality of private language schools, but those at the forefront offer high-quality education and adhere closely to European standards. In addition, the professional development of foreign language teachers focuses on teaching and assessing according to the aims of the CEFR and its levels. Cambridge ESOL has recently introduced an award in Serbia, whereby it recognises exceptional efforts by language schools and rewards them for preparing candidates for their exams. The awards are public and schools can use them for advertising purposes, which further motivates them to popularise Cambridge ESOL exams.

There exist a number of internationally recognised tests in Serbia which give an accurate and true reflection of candidates' communicative competence across the four skills, and the exam tasks are designed in such a way as to reflect real-life skills needed in actual language situations. Among them are the world's leading range of Cambridge ESOL examinations, then IELTS, TOEFL, LCCI (London Chamber of Commerce and Industry Examinations Board) certificates, French DELF and DALF, German standardised examinations for the Goethe-Zertifikat, DaF (Deutsch als Fremdsprache), Spanish D.E.L.E. examinations (Los Diplomas de Español como Lengua Extranjera), Italian CELI (Certificato di Conoscenza della Lingua Italiana), Chinese HSK (Hanyu Shuiping Kaoshi), Russian TRKI (Тест по русскому языку как иностранному), to mention but a few. Our intention at this point is not to burden the reader with hardcore statistical analyses (though part of these will have to be mentioned), but rather to call attention to how some of these high-stakes tests are used locally, for education or employment purposes, and to emphasise the need for more professional responsibility and research in standard setting in the Serbian education context.

As regards the pass rates for the internationally recognised examinations only the statistics for the French DELF and DALF (see APPENDIX 1) and Cambridge ESOL Main Suite examinations (see APPENDIX 2) could be obtained. It must be emphasised that Cambridge ESOL Main Suite examinations have established dominance over other examinations equally recognised worldwide. The most popular Cambridge ESOL examination is First Certificate in English. It is important to point out that about 250,000 candidates take it annually, $75 \%$ of which are below 25 years of age. The reasons for taking it are predominantly for their career (more than half), for further study (about a third), or for personal interest (one in six). Since BEC (Business English Certificates) 
was introduced, some candidates have shifted from FCE/CAE to BEC, thus removing more of the business oriented candidates. The pass rates, as can be seen in APPENDIX 2, are rather high for all the levels, though it is somewhat smaller for the CPE (Certificate of Proficiency in English), which is understandable since it requires a certain level of maturity and approaches the linguistic competence of an educated native speaker. Much credit for such good pass rates goes to private foreign language schools.

\section{SERBIAN AS A FOREIGN LANGUAGE}

In recent years there has been a growing interest in learning Serbian as a foreign language, which has resulted in better organization and a higher degree of uniformity in the design of the syllabus for Serbian as a foreign language. To illustrate, in 2002/2003 the Centre for Serbian as a foreign language was established at the Department of Serbian language and linguistics, Faculty of Philosophy, University of Novi Sad. Learners learn Serbian and get acquainted with the country's culture and history. The courses offered are: preparatory instruction, preparatory year of studies, semester courses, and individual courses (Subotić/Bjelaković 2007). As for the profile of learners they range from:

- foreign students of Slavic studies,

- foreign students and researchers who participate in international studentexchange programmes and projects like (Campus Europae, CEEPUS (Central European Exchange Program for University Studies), DAAD (Deutscher Akademischer Austausch Dienst), Tempus, etc.),

- $\quad$ heritage speakers (expatriates),

- all foreign citizens who wish to learn standard Serbian and obtain certificates as proof of standard Serbian language proficiency.

The centre has done much to encourage the adoption of the CEFR. The syllabus has been designed to relate learner performance to CEFR levels. The CEFR is thus used as a benchmark for designing courses, textbooks and tests respectively. We must also emphasise that distinguished Serbian linguists, language and teaching experts from the same Department defined the Threshold level for Serbian as a foreign language, which has not been published yet. Work on the remaining reference level descriptors for Serbian is in progress. These professors and their associates are among the true enthusiasts in our country who evidently do not lack motivation, but would highly appreciate the expertise, experience and support of specialists in language testing and assessment in order to better understand and use language assessment for the stated purposes, as well as for the accreditation of the examination centre and the construction and administration of the tests. 


\section{CONCLUSION}

In conclusion, internationally recognised language tests have created enormous washback, because their popularity has raised awareness of standardised language testing in the teaching community as well as the general public. We would like to stress that the number of candidates is constantly rising year by year, including young learners, which reflects a heightened awareness on the part of the parents of the increasing importance of international language qualifications (see APPENDIX 3).

Despite the good grades and recognition of international certificates by highquality language schools, what is still missing is their full recognition and integration into the education system, namely state-run schools and universities, due to a general lack of coordination and regulation. If the situation remains unchanged, we run the risk of creating doubt in the general public regarding the usefulness of taking international examinations. Many candidates and parents still have to rely on the vague explanation that these examinations are widely recognised and thus very useful for furthering one's career and education, which is after all why most of them opt for sitting such exams.

Given that a truly European dimension in language education has been embraced in Serbia, all educational establishments must show that it is in the country's best interest and therefore do everything in their power to facilitate its implementation. Despite all the problems, we firmly believe that standardised foreign language testing in Serbia shall successfully be implemented, ushering in a new era of European-class education. After all, an entire new generation of young people reared on the idea of internationally recognised language examinations is reaching maturity and slowly becoming the dominant part of the population and the idea of standardisation in language testing is something they will readily accept.

\section{REFERENCES}

Bodrič, R. 2007. Zajednički evropski okvir za žive jezike - evropska dimenzija obrazovanja. Misao: revija za obrazovanje i kulturu, avgust/septembar 2007, 9-11.

Bodrič, R. 2008. The Common European Framework of Reference for Languages and European Language Portfolio - Languages without Frontiers. U D. Točanac i M. Jovanović (ur.) Drugi međunarodni kongres Društva za primenjenu lingvistiku Srbije „Primenjena lingvistika danas”: zbornik radova. Novi Sad: Društvo za primenjenu lingvistiku Srbije, 297-303.

Graddol, D. 2006. English Next. London: The British Council.

Subotić, Lj. i I. Bjelaković. 2007. Centar za srpski jezik kao strani na Filozofskom fakultetu u Novom Sadu (iskustva i perspektive). U M. Dešić (ur.) Srpski kao strani jezik u teoriji i praksi: Zbornik radova. Beograd: Filološki fakultet, Centar za srpski kao strani jezik, 173-183.

Vlaisavljević, A. 2006. Future Trends in ELT and Their Applicability to the Serbian National Curriculum. U M. Knežević i A. Nikčević-Batrićević (ur.) Reading Across Borders: Papers in Language and Literary Studies. Nikšić: Filozofski fakultet, 235-245. 


\section{SUMMARY}

\section{SETTING COMMON STANDARDS IN FOREIGN LANGUAGE TESTING - ALIGNING SERBIA WITH THE REST OF THE WORLD}

The aim of this paper is to give an overview of foreign language testing in Serbia, its current state and possible steps towards implementing a unified standard and the long-term benefits such a unification would bring to the quality of language testing and foreign language education in general. This, coupled with the fact that such a standard would prevent redundant testing and the unnecessary waste of effort by both teachers and students, makes setting standards a necessity and not an option.

KEYWORDS: foreign language testing, Serbia, unified standard, teachers, students. 


\section{APPENDIX 1}

\section{EXAM STATISTICS FOR FRENCH EXAMINATIONS (ALL CENTRES), SERBIA, UNTIL 5 MARCH 2008}

Examination A1

\begin{tabular}{|l|l|l|l|l|l|}
\hline Year & Applied & Present & Passed & Applied/Present & Passed \\
\hline 2005 & 35 & 34 & 34 & $97,14 \%$ & $100 \%$ \\
\hline 2006 & 240 & 222 & 221 & $92,50 \%$ & $99,55 \%$ \\
\hline 2007 & 228 & 218 & 217 & $95,61 \%$ & $99,54 \%$ \\
\hline A1 total until 05-03-08 & 503 & 474 & 472 & $94,23 \%$ & $99,58 \%$ \\
\hline
\end{tabular}

Examination A2

\begin{tabular}{|l|l|l|l|l|l|}
\hline Year & Applied & Present & Passed & Applied/Present & Passed \\
\hline 2005 & 65 & 62 & 59 & $95,38 \%$ & $95,16 \%$ \\
\hline 2006 & 215 & 201 & 198 & $93,49 \%$ & $98,51 \%$ \\
\hline 2007 & 222 & 210 & 205 & $94,59 \%$ & $97,62 \%$ \\
\hline A2 total until 05-03-08 & 502 & 473 & 462 & $94,22 \%$ & $97,67 \%$ \\
\hline
\end{tabular}

Examination B1

\begin{tabular}{|l|l|l|l|l|l|}
\hline Year & Applied & Present & Passed & Applied/Present & Passed \\
\hline 2005 & 63 & 60 & 45 & $95,24 \%$ & $75,00 \%$ \\
\hline 2006 & 131 & 123 & 110 & $93,89 \%$ & $89,43 \%$ \\
\hline 2007 & 154 & 149 & 133 & $96,75 \%$ & $89,26 \%$ \\
\hline B1 total until 05-03-08 & 348 & 332 & 288 & $95,40 \%$ & $86,75 \%$ \\
\hline
\end{tabular}

Examination B2

\begin{tabular}{|l|l|l|l|l|l|}
\hline Year & Applied & Present & Passed & Applied/Present & Passed \\
\hline 2005 & 24 & 23 & 17 & $95,83 \%$ & $73,91 \%$ \\
\hline 2006 & 73 & 70 & 36 & $95,89 \%$ & $51,43 \%$ \\
\hline 2007 & 82 & 78 & 59 & $95,12 \%$ & $75,64 \%$ \\
\hline B2 total until 05-03-08 & 179 & 171 & 112 & $95,53 \%$ & $65,50 \%$ \\
\hline
\end{tabular}

Examination C1

\begin{tabular}{|l|l|l|l|l|l|}
\hline Year & Applied & Present & Passed & Applied/Present & Passed \\
\hline 2005 & 8 & 8 & 6 & $100 \%$ & $75,00 \%$ \\
\hline 2006 & 24 & 21 & 14 & $87,50 \%$ & $66,67 \%$ \\
\hline 2007 & 17 & 17 & 10 & $100 \%$ & $58,82 \%$ \\
\hline C1 total until 05-03-08 & 49 & 46 & 30 & $93,88 \%$ & $65,22 \%$ \\
\hline
\end{tabular}


Examination C2

\begin{tabular}{|l|l|l|l|l|l|}
\hline Year & Applied & Present & Passed & Applied/Present & Passed \\
\hline 2006 & 1 & 1 & 0 & $100 \%$ & $0,00 \%$ \\
\hline 2007 & 1 & 1 & 0 & $100 \%$ & $0,00 \%$ \\
\hline C2 total until 05-03-08 & 2 & 2 & 0 & $100 \%$ & $0,00 \%$ \\
\hline
\end{tabular}

Information included by permission of the French Cultural Centre, Belgrade, Serbia

\section{APPENDIX 2}

Cambridge ESOL Main Suite Exam Grade Statistics in Serbia and Montenegro 2004-2006

\begin{tabular}{|l|l|l|l|l|l|}
\hline \multicolumn{6}{|l|}{ KET (Key English Test) (A2) } \\
\hline Year & Pass with Merit & Pass & Total Pass & Narrow Fail & Fail \\
\hline 2004 & n/a & n/a & n/a & n/a & n/a \\
\hline 2005 & $77 \%$ & $23 \%$ & $\mathbf{1 0 0} \%$ & $0 \%$ & $0 \%$ \\
\hline 2006 & $73.1 \%$ & $25.0 \%$ & $\mathbf{9 8 . 1} \%$ & $0.9 \%$ & $0.9 \%$ \\
\hline
\end{tabular}

\section{PET (Preliminary English Test) (B1)}

\begin{tabular}{|l|l|l|l|l|l|}
\hline Year & Pass with Merit & Pass & Total Pass & Narrow Fail & Fail \\
\hline 2004 & $49 \%$ & $46 \%$ & $\mathbf{9 4 \%}$ & $2 \%$ & $4 \%$ \\
\hline 2005 & $45 \%$ & $44 \%$ & $\mathbf{8 9 \%}$ & $6 \%$ & $5 \%$ \\
\hline 2006 & $49 \%$ & $43 \%$ & $\mathbf{9 2} \%$ & $3 \%$ & $5 \%$ \\
\hline
\end{tabular}

\section{FCE (First Certificate in English) (B2)}

\begin{tabular}{|l|l|l|l|l|l|l|l|}
\hline Year & Session & Grade A & Grade B & Grade C & Total Pass & Grade D & Grade E \\
\hline \multirow{3}{*}{2004} & March & n/a & n/a & n/a & n/a & n/a & n/a \\
\cline { 2 - 8 } & June & $16 \%$ & $34 \%$ & $32 \%$ & $\mathbf{8 2} \%$ & $8 \%$ & $11 \%$ \\
\cline { 2 - 8 } & December & $21 \%$ & $31 \%$ & $31 \%$ & $\mathbf{8 3} \%$ & $8 \%$ & $9 \%$ \\
\hline \multirow{3}{*}{2005} & March & n/a & n/a & n/a & n/a & n/a & n/a \\
\cline { 2 - 8 } & June & $17 \%$ & $32 \%$ & $37 \%$ & $\mathbf{8 5} \%$ & $5 \%$ & $10 \%$ \\
\cline { 2 - 8 } & December & $21 \%$ & $36 \%$ & $31 \%$ & $\mathbf{8 9} \%$ & $2 \%$ & $9 \%$ \\
\hline \multirow{3}{*}{2006} & March & $25 \%$ & $15 \%$ & $38 \%$ & $\mathbf{7 8} \%$ & $13 \%$ & $10 \%$ \\
\cline { 2 - 8 } & June & $18 \%$ & $33 \%$ & $35 \%$ & $\mathbf{8 5} \%$ & $6 \%$ & $9 \%$ \\
\cline { 2 - 8 } & December & $16 \%$ & $31 \%$ & $37 \%$ & $\mathbf{8 5} \%$ & $6 \%$ & $9 \%$ \\
\hline
\end{tabular}

\begin{tabular}{|c|c|c|c|c|c|c|c|}
\hline \multicolumn{8}{|c|}{ CAE (Certificate in Advanced English) (C1) } \\
\hline Year & Session & Grade A & Grade B & Grade C & Total Pass & Grade D & Grade E \\
\hline \multirow{3}{*}{2004} & March & $\mathrm{n} / \mathrm{a}$ & n/a & $\mathrm{n} / \mathrm{a}$ & n/a & $\mathrm{n} / \mathrm{a}$ & n/a \\
\hline & June & $8 \%$ & $18 \%$ & $42 \%$ & $68 \%$ & $15 \%$ & $17 \%$ \\
\hline & December & $12 \%$ & $14 \%$ & $47 \%$ & $72 \%$ & $12 \%$ & $16 \%$ \\
\hline
\end{tabular}




\begin{tabular}{|l|l|l|l|l|l|l|l|}
\hline \multirow{3}{*}{2005} & March & n/a & n/a & n/a & n/a & n/a & n/a \\
\cline { 2 - 7 } & June & $10 \%$ & $12 \%$ & $48 \%$ & $\mathbf{7 0 \%}$ & $10 \%$ & $20 \%$ \\
\cline { 2 - 8 } & December & $13 \%$ & $21 \%$ & $46 \%$ & $\mathbf{7 9 \%}$ & $7 \%$ & $14 \%$ \\
\hline \multirow{3}{*}{2006} & March & $8 \%$ & $16 \%$ & $36 \%$ & $\mathbf{6 0 \%}$ & $4 \%$ & $36 \%$ \\
\cline { 2 - 8 } & June & $7 \%$ & $17 \%$ & $52 \%$ & $\mathbf{7 7 \%}$ & $6 \%$ & $18 \%$ \\
\cline { 2 - 8 } & December & $10 \%$ & $15 \%$ & $51 \%$ & $\mathbf{7 7 \%}$ & $10 \%$ & $14 \%$ \\
\hline
\end{tabular}

\begin{tabular}{|l|l|l|l|l|l|l|l|}
\hline \multicolumn{2}{|l|}{ CPE (Certificate of Proficiency in English) (C2) } \\
\hline Year & Session & Grade A & Grade B & Grade C & Total Pass & Grade D & Grade E \\
\hline \multirow{2}{*}{2004} & June & $11 \%$ & $12 \%$ & $46 \%$ & $\mathbf{6 9} \%$ & $8 \%$ & $22 \%$ \\
\cline { 2 - 8 } & December & $14 \%$ & $20 \%$ & $28 \%$ & $\mathbf{6 1 \%}$ & $10 \%$ & $29 \%$ \\
\hline \multirow{2}{*}{2005} & June & $7 \%$ & $16 \%$ & $39 \%$ & $\mathbf{6 3} \%$ & $10 \%$ & $28 \%$ \\
\cline { 2 - 8 } & December & $12 \%$ & $19 \%$ & $39 \%$ & $\mathbf{7 0 \%}$ & $7 \%$ & $22 \%$ \\
\hline \multirow{2}{*}{2006} & June & $7 \%$ & $18 \%$ & $50 \%$ & $\mathbf{6 5 \%}$ & $10 \%$ & $25 \%$ \\
\cline { 2 - 8 } & December & $21 \%$ & $18 \%$ & $27 \%$ & $\mathbf{6 7 \%}$ & $10 \%$ & $24 \%$ \\
\hline
\end{tabular}

Source: www.cambridgeesol.org

\section{APPENDIX 3}

Statistics illustrating the steady rise in the number of ESOL candidates in Serbia from 2004 to 2009

\begin{tabular}{|l|l|}
\hline Year & No. of ESOL candidates in Serbia (approx.) \\
\hline 2004 & 2,300 \\
\hline 2005 & 2,500 \\
\hline 2006 & 2,900 \\
\hline 2007 & 3,100 \\
\hline 2008 & 3,400 \\
\hline 2009 & 3,400 \\
\hline
\end{tabular}

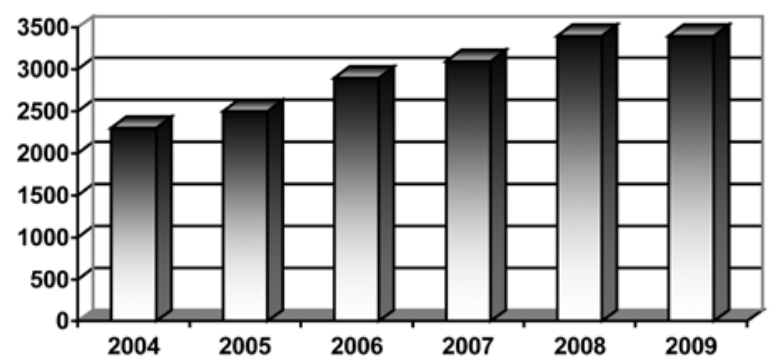


The rise and fall in the number of candidates taking particular examinations:

\begin{tabular}{|l|l|l|l|l|}
\hline Year & YLE (Young Learners English) Exam & FCE Exam & CAE Exam & CPE Exam \\
\hline 2005 & $-3 \%$ & $+20 \%$ & $+15 \%$ & $-6 \%$ \\
\hline 2006 & $+20 \%$ & $+18 \%$ & $+9 \%$ & $-5 \%$ \\
\hline 2007 & $+80 \%$ & $-7 \%$ & $+20 \%$ & $-8 \%$ \\
\hline 2008 & n/a & n/a & n/a & n/a \\
\hline 2009 & $-3 \%$ & $+5 \%$ & $-16 \%$ & $+7 \%$ \\
\hline
\end{tabular}

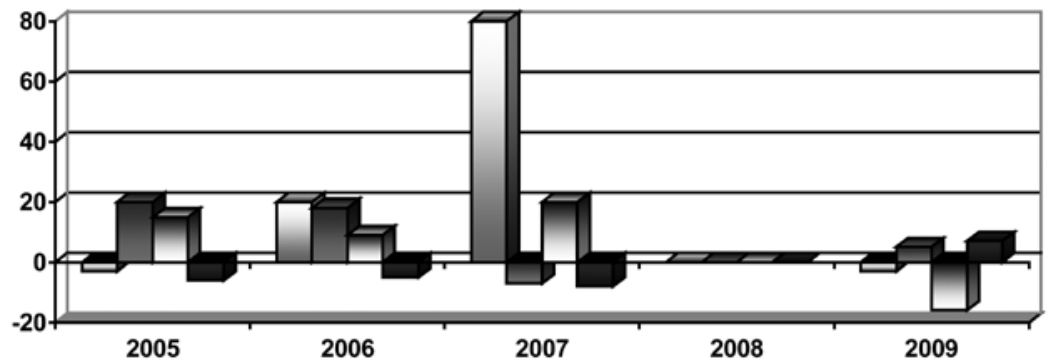

Information included by permission of the British Council, Belgrade, Serbia.

(Original scientific paper received 01.02.2011; revised 04.07.2011; accepted 01.09.2011) 